-158-（61）抄録

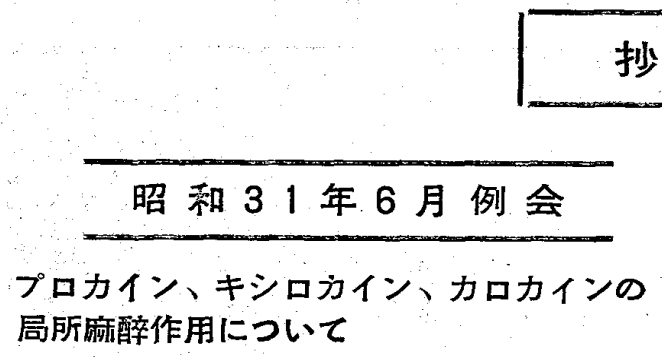

葲 理 内讪正勝、吉村泰治

我々は Procaine, Xylocaine، Calocain の局所森

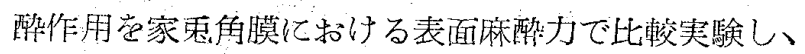

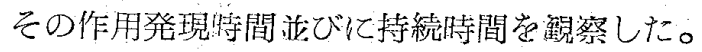

実験には $2 \mathrm{~kg}$ 前捘の健康家鬼を使用し、高息式標 準滴瓶にて、被検局所麻酰液を一滴点眼し、1/4及び $1 / 1$ 注射針用マシドリンを上四天柈にて測定し、 $4.0 \mathrm{~g}$ 、

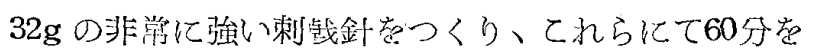

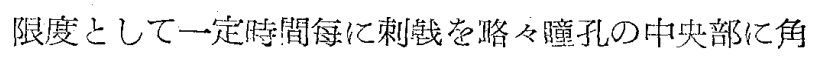
膜を可及的傷害するととなく加党、角膜反射消失の有 無を㭘した。被梌液は、Procaine(局方)Calocain(森下 製薬）は、g/dl法で、0.5\%、1\%、2\%、3\%、4\%の各浱度

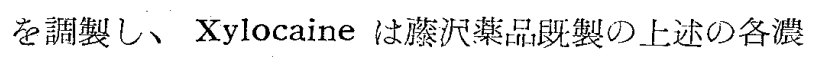
度を使用した。対照には片眼々生理食塩液を用いた。

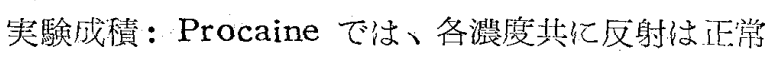
であり表面麻酥はなかつた。Calocain では、作用発 現時間と持続特間は、それぞれ、0.5\%は、反射正営、 $1 \%$ 、 3 分と7分、 $2 \% 、 3 \%$ ば、 2 分之18分、 $4 \%$ で は2分と38分であつだ Xylocaine では、0.5\%、1\%。 $2 \%$ 反射は正常、 $3 \%$ は分と2分、 $4 \%$ は分之 4 分 であつた。以上の如く、Xylocaine は Calocain に 比し、作用発現は速やかであるが、持続封間は短い。

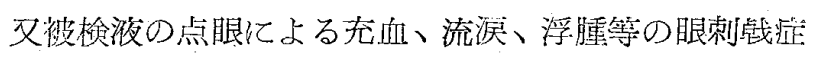
状は、認められなかつた。

\begin{tabular}{|c|c|c|}
\hline & $\begin{array}{l}\text { 作用 } \\
\text { 発現 } \\
\text { 闍聞 } \\
\text { (分) }\end{array}$ & $\begin{array}{l}\text { 作用 } \\
\text { 赫続 } \\
\text { 将留 } \\
\text { (分) }\end{array}$ \\
\hline $\begin{array}{l}\text { Procaine } \\
0.5 \%-4 \%\end{array}$ & 0 & 0 \\
\hline $\begin{array}{r}\text { Xylocaine } \\
0.5 \%-2 \% \\
3 \% \\
4 \%\end{array}$ & $\begin{array}{l}0 \\
2 \\
1\end{array}$ & $\begin{array}{l}0 \\
2 \\
4\end{array}$ \\
\hline $\begin{array}{r}\text { Calocain } \\
0.5 \% \\
1 \% \\
2 \% \\
3 \% \\
4 \%\end{array}$ & $\begin{array}{l}0 \\
3 \\
2 \\
2 \\
2\end{array}$ & $\begin{array}{r}0 \\
7 \\
18 \\
18 \\
38\end{array}$ \\
\hline
\end{tabular}

質問 口外 平川

局所麻酔の毒性並に安全の量はどれだけか。

\section{解答 演者}

この点に就ては未だ実験は行つていない。

\section{銀バラジウム合金線の彈性に就て \\ 第 2 報 耐蝕性に及ぼす熱処理効果}

理 $x$ 山 根 证次

銀パラ合金線の弹力に及法す蓺处理の影響に就て は、第一報で発表したが、この熱处現が使用侍の耐蝕 性に及媇す影響に就て第 2 報として報告する。

銀パラ合金は現在見出されている銀合金中最も耐蝕 性が秀れているもの之考光られているが、使用に際し てはその熱处理効果觉生汃して、軟化处理或は硬化处 理聕ほどしして、その使用に応じて、適当する物理的 性質を与它るのである。てのような熱处理仙合金の内

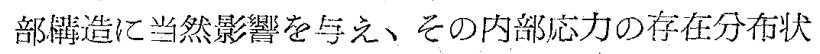
態がその合金の付蝕性にも又影響するここが年想され る。

筆者は一種の遮速哳玲試験法（R. G. Y法）を用い て、その影響を電気化学的传考察したが、その精度が 内部応力の影響党感ずる程のものでなく、その口腔内

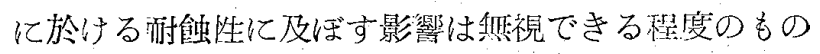
であることが判つた。

即ち、直径 $1 \mathrm{~mm}$ の銀パラ合金線（ $\mathrm{Ag} 49.22 \%$ 。 Pd $23.96 \%$ 、Au $1.37 \%$ 、Cu $13.86 \%$, Zu $1.04 \%$ 、Cd

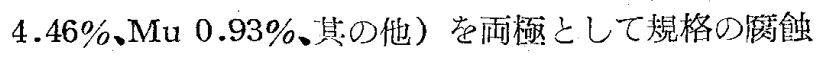

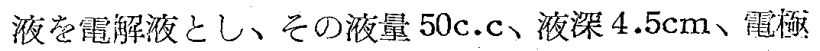
浸筫 $1 \mathrm{~cm}$ 、歌間距離 $2 \mathrm{~cm}$ とし $1 \mathrm{~V}, 1$ 分の割で $6 \mathrm{~V}$ まで

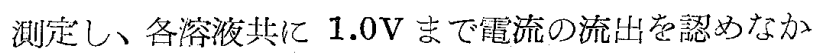
つた。

ての絬果、銀パラ合金の熱処理は臨床的には影響が ないものと判定することができたと考える。

\section{乳酸菌のビ文ミン利用と表面活性剂}

生化学、松下義婎、大明康男

東大農学部灾朋微生物研究所よりもらい受けた乳酸 菌株を男いて二ヨチン酸とパントテン酸に刘する L. arabinosus, Leuco,mesenteroides $の$ 発育曲線觉 調べた。同時に所謂 uniform medium の上に更に 表面活性剂 Tween 80、水醌酸、タエン酸アンモン等

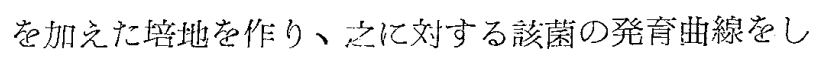

